\title{
Urinary excretion of purine derivatives in goats
}

\section{J.E. LINDBERG}

Swedish University of Agricultural Sciences, Dept. of Animal Nutrition and Management, S-750 07 Uppsala, Sweden

Four experiments were conducted to study urinary excretion of purine derivatives (i.e. allantoïn, uric acid, hypoxanthine, xanthine) in goat kids. Estimates of microbial $\mathrm{N}$ synthesis in dairy goats were calculated from allantoïn excretion and from results obtained in goat kids.

In Expt 1 three male kids were bottle fed with goat milk and goat milk gradually supplemented with $\mathrm{N}$-free liquid (18.6 p. 100 butter-fat, 4.0 p. 100 lactose) down to 20 p. 100 goat milk in the diet and back to all goat milk. Energy intake was kept constant at $800 \mathrm{~kJ} \mathrm{GE} / \mathrm{W}^{0.75}$. In Expt 2 three male kids were bottle fed with goat milk and increments of RNA. Energy intake was kept constant at $800 \mathrm{~kJ} \mathrm{GE} / \mathrm{W}^{0.75}$. In Expt 3 three male kids and three female kids were weaned from all liquid feeding in bottle to a dry basal diet (hay : concentrate) plus liquid feeding in bottle. RNA was given in increments in the liquid feed. In Expt 4 three male kids were bottle fed with goat milk at four levels of intake $\left(400,600,800\right.$ and $\left.1000 \mathrm{~kJ} \mathrm{GE} / \mathrm{W}^{0.75}\right)$ in two periods (at 2 and at 8 weeks of age).

With decreasing $\mathrm{N}$ intake (1 $222 \mathrm{mg} \mathrm{N} / \mathrm{W}^{0.75}$ to $\left.223 \mathrm{mg} \mathrm{N} / \mathrm{W}^{0.75}\right)$, urinary allantoin- $\mathrm{N}$ (All-N) and uric acid-N (Ua-N) excretion decreased $(9.4$ to $6.8 \mathrm{mg}$ All-N/W0.75; 2.6 to $1.0 \mathrm{mg}$ Ua-N/W0.55), but returned to initial values with increasing $\mathrm{N}$ intake. No consistent excretion pattern was observed for hypoxanthine. Xanthine was not detectable in the urine.

Excretion of All-N was markedly increased by the increased intake of RNA, while there was a less pronounced increase in the excretion of Ua- $N$, hypoxanthine- $N$ and xanthine- $N$. Changes in the level of feed intake did not markedly affect urinary excretion of purine derivatives. The level of All-N excretion was similar at 2 and 8 weeks of age.

Lactating dairy goats were fed hay : concentrate $(40: 60)$ either without protein supplement or with varying proportions of urea $(0.9,1.8,2.7,3.5 \mathrm{p} .100)$ or fish meal $(3.9,7.9,11.7,15.8$ p. 100). All diets were fed ad libitum with an adaptation period of at least 2 weeks to a new diet. Feed intake was 800 to $1800 \mathrm{~g}$ digestible organic matter/d. Urine and faeces were collected for 2 weeks. The relationship between urinary allantoin excretion $(\mathrm{mg} / \mathrm{d})$ and intake of $(\mathrm{g} / \mathrm{d})$ digestible organic matter (DOM) and digestible crude fibre and nitrogen free extracts $(\mathrm{DCHO})$ was : All-N $=1.204 \mathrm{DOM}-156.7$, $\mathrm{n}=67, \mathrm{r}=0.83$, c.v. $=14.8$ p. $100, \mathrm{SD}=190$. All-N $=1.459$ DCHO $-109.3, \mathrm{n}=67$, $\mathrm{r}=0.81$, c.v $=15.4$ p. $100, \mathrm{SD}=198$. If we assume a conversion rate of RNA-N to All-N of $50 \mathrm{p} .100$, a RNA-N content of microbial-N of $11.4 \mathrm{p} .100$, a true intestinal digestibility of RNA-N of 87 p. 100 and a proportion of amino-acid $N$ in microbial-N of 0.80 , the flow of microbial amino acid-N was $19.6 \mathrm{~g} / \mathrm{kg}$ DOM and $23.7 \mathrm{~g} / \mathrm{kg}$ DCHO. These estimates are in very good agreement with other published values.

Key words : Purine excretion, goat, microbial protein, kids. 